Nevşehir Bilim ve Teknoloji Dergisi TARGíD Özel Sayı 9-18 2016

DOI: 10.17100/nevbiltek.210954

URL: http://dx.doi.org/10.17100/nevbiltek.210954

\title{
Nevşehir Yöresindeki Doğal Depoların Modern Depolarla Karşılaştırılması
}

\author{
İbrahim Örüng ${ }^{1}$, Sedat Karaman ${ }^{2, *}$, Ünal Şirin ${ }^{1}$ \\ ${ }^{1}$ Atatürk Üniversitesi Ziraat Fakültesi, Tarımsal Yapılar ve Sulama Bölümü, Erzurum \\ ${ }^{2}$ Gaziosmanpaşa Üniversitesi, Ziraat Fakültesi, Biyosistem Mühendisliği Bölümü, Tokat \\ Öz
}

Depolama yapıları; yetiştirme mevsimi dışında üründen yararlanmayı, üreticinin pazar fiyatlarını izleyerek ürünün uygun zamanlarda uygun fiyatlarla pazara sürümünü, tüketicinin pazarda uzun süre daha nitelikli ve uygun fiyatlarla ürün bulmasını, üretim ve pazarlama işlerinin iş gücünün yıl içerisinde dengeli şekilde dağılımını, ürünü değerlendiren sanayinin daha uzun süre ve ekonomik olarak çalışma olanağı bulmasını sağlamaktadır.

Bu çalışmada; Nevşehir yöresinde tarımsal ürünlerin depolanası amacıyla kullanılan volkanik tüf kaya depolama sistemi hakkında bilgi verilmiştir. Yöredeki tüf kayalarına oyulan depolarda yalnızca deponun soğuk havasından yararlanılarak sebze ve meyveler enerji harcanmadan depolanabilmekte, bu da büyük maliyet üstünlüğü sağlamaktadır. Bacasız fabrikalar özelliğindeki bu depolar, ülke ve bölge ekonomisine büyük katkı yapmakta, önemli istihdam olanağı sağlamaktadır.

Anahtar Kelimeler: Depolama, yer altı depoları, Nevşehir

\section{Natural Storages Versus Modern Storages In Nevsehir Region}

\section{Abstract}

Storage structures allow the producers to benefit from the products out of the season, to market their products in proper periods with proper market prices through monitoring the market prices, to provide a balanced labor distribution in production and processing activities throughout the year, allow the consumer to find quality products in markets with proper prices for longer durations, allows the producers and finally allow the relevant industries to work economically for longer durations.

Information provided in this study about the natural storages made of volcanic tufa rock storage system used to store agricultural products. The storages are carved into tufa rock in the region and used as cold storage for vegetables and fruits without using any energy. The system has significant cost-advantages over the conventional modern storages. Such systems are also called as “factories without chimneys". They are able to provide significant contributions to local and country economy and also provide significant employment opportunities.

Keywords: Storage, underground storages, Nevşehir

*e-mail: sedat.karaman@gop.edu.tr 


\section{Giriş}

Depolama, derimi belirli bir mevsim içerisinde olan ve bu mevsimde sahip oldukları kaliteyi olanaklar ölçüsünde kaybetmeden, üretimin olmadığı sonraki aylarda tüketilebilmesini sağlayan diğer bir ifadeyle ürünün daha sonra pazarlanmak üzere kalitesini koruyacak koşullarda belirli bir süre düşük sıcaklık ve yüksek nem içeren ortamlarda bekletilmesi işlemi olarak ifade edilebilir [1 ve 2].

Depolamanın amacı, kötü hava koşullarının etkisi, böceklerin ve mikro organizmaların zararlı faaliyetleri, su kaybıyla solma ve büzülme oluşması gibi arzu edilmeyen koşullara engel olarak derimi yapılan ürünlerde olgunlaşmayı yavaşlatmak ve tazeliğini sürdürmektir [3]. Ürünlerin deriminin en uygun zamanda yapılması ve derim sonrası teknolojisinin gerektiği şekilde uygulanmaması ile depolama sırasında çürüme, bozulma ve fizyolojik bozukluklar ortaya çıarak kayıplar yüksek değerlere ulaşmakta, bu da ülke ekonomisini olumsuz yönde etkilemektedir. Bu kayıpların en düşük düzeye indirilebilmesi, ürünlerin uygun derim devrelerinde toplanması ve uygun koşullarda depolanması ile olasıdır [4].

Üretim artışına bağlı olarak soğuk hava depolarının sayısının son yıllarda hızla arttığı Türkiye’de 119 depoya sahip olan İzmir birinci sırada olup, bunu 97 depoyla Gaziantep, 91 depoyla İstanbul ve Manisa, 82 depoyla Adana ve 71 depoyla Isparta illeri takip etmektedir [5].

Depolama özellikleri bakımından en uzun süre depolanabilen ürünlerden birisi olan elma, Türkiye'de yaygın olarak yetiştirilmesine karşın, ticari anlamda istenilen noktaya ulaşılamamıştır. Elmacılık faaliyetlerinin yoğun yapıldığı illerde depoculuk faaliyetlerinin de buna paralel olarak arttı̆̆ dikkat çekmektedir. Özellikle Isparta, Denizli, Konya, Karaman, Amasya, Niğde ve Antalya bu illerden bazılarıdır. Ayrıca bu illerden hasat edilen elmaların bir kısmı, pazar potansiyeli fazla olan İstanbul ve İzmir gibi merkezlere getirilerek buralarda depolanmakta ve zamanı geldiğinde pazarlanmaktadır. Pazarlama olanaklarının fazla olduğu bu merkezlerde depo sayıları da artış göstermiştir. Ülkemizde en çok depolanan ürünler elma, armut, ayva, kiraz, şeftali, kayısı, vişne, soğan, üzüm, nar, portakal, limon, erik, greyfurt, patates, domates, avokado ve kividir. Bu ürünlerin saklandığı depolar ağırlıklı olarak bu ürünlerin yetiştirildiği çevrelerde yoğunlaşmıştır [5].

Bunun dışında Nevşehir, Niğde ve Aksaray'da volkanik arazideki dirençsiz malzeme oyularak veya kazılarak adi depolar oluşturulmaktadır. Bölgede bu amaçla oluşturulmuş soğuk hava deposu olarak kullanılan yaklaşık 2000 volkanik tüf deposu bulunmaktadır. Bazı ticari firmalar bu kaya mağaralarında altmış bin ton patates depolayabilmektedir [6]. Bu depolar için hiçbir soğutucu aygıt kullanılmamakta, yalnızca bu malzemenin sağladığı doğal serinletme olanaklarından yararlanılmaktadır. Bu depolarda ağırlıklı olarak depolanan ürünler narenciye, patates, elma ve soğandır [5]. Bu çalışmada Niğde ve Nevşehir yörelerinde tarımsal ürünlerin depolanması amacıyla kullanılan volkanik tüf kaya depolama sistemi hakkında bilgi verilmiştir.

\section{Depolama Yöntemleri}

Depolama sistemleri; doğal soğutmalı, yapay soğutmalı ve kontrollü atmosfer depolarda muhafaza olarak siralanabilir [7].

Doğal soğutmalı depolarda muhafaza: Tarımsal ürünlerin saklanmasında kullanılan kiler, samanlık, toprak altında bulunan doğal ve yapay mağaralar şeklindeki bu depolarda, kış aylarında depo 
kapatılarak ürün dondan korunmaktadır. Bağıl nem toprak neminden yararlanılarak veya su serpilerek yüksek tutulmakta, konveksiyonla havalandırma sinırlı kalmaktadır [8].

Basit depolarda, sistem; soğuk olan dış ortam havasının, doğal veya zorunlu konveksiyonla depo içerisine alınıp ürünün soğutulmasına dayanmaktadır. Basit depolarda iyi bir 1sı ve nem yalıtımı gerekir. Bu tip depoların yapımı ve işletilmesi kolay ve ucuzdur. Özellikle gece ve gündüz sıcaklık farklılıklarının büyük olduğu karasal iklim bölgelerinde başarıyla kullanılmaktadır. Toprak altında kalan yüzeylerde isı yalıtımı yapılmayabilir [9].

Ürünlerin depolanmasında yararlanılan ve toprak altına açılmış basit çukurlar en basit depo tipidir. Basit depolar; toprak altında, üstünde ve kısmen toprak içinde yapılabilir. Ürünler, tarım işletmelerinde yapıların bodrum katlarında veya kilerlerde de depolanabilir. Havalandırma için duvar ve tabanda havalandırma kanalları da oluşturularak, bodrum katı ürün için uygun bir depo durumuna getirilebilir. Depo sıcaklığı kontrol edilemediği için \% 20'den fazla kayıp oluşmaktadır. Kilerlerin temiz, havalanabilir, serin ve dışarıdan ışık almaması gerekir [10 ve 11].

Toprak yüzeyinde yapılan basit depolar dışında, Nevşehir yöresinde bulunan doğal depolar toprak altındadır. Depolama süresi, sıcaklık kontrollünün sağlanabildiği mekanik soğutmalı depolamaya göre daha kısadır [12].

\section{Basit depoların üstünlükleri}

a. Teknikle soğutulan depoların tesis ve işletme masraflarının fazla olmasına karşın, basit depolarda bu masraflar oldukça düşüktür. Nitekim basit depolarda yalıtım ve soğutucu ekipman masrafları söz konusu değildir.

b. İnşaat tesis giderleri çok azdır.

c. Basit depolarda işletme masrafları soğuk hava depolarına oranla az olduğundan, depolanan ürünlerin birim maliyeti soğuk hava depolarına göre daha düşüktür.

d. Basit depolarda saklanan ürünlerin daha ucuz olmasına ek olarak basit depolarda saklanan ürünler, perakende satışlarda manavlar tarafindan daha çok tercih edilmektedir. Çünkü soğuk hava depolarında saklanan ürünler manavlarda soğutucu cihazlar bulunmadığından kısa bir sürede bozulmaya yüz tutmaktadır. Basit depolarda yalnızca hava akımı ve nemin etkisiyle soğumakta olduğundan, buralarda muhafaza edilebilen ürünler perakende mağazalarında uzun süre dayanmaktadır [13 ve 5].

Buna karşın basit depolama sistemlerinin; depolama yöntemlerinin ilkel olması, ortamın nem ve gaz kontrolünün tam olarak sağlanamaması nedeniyle kalite kayıplarının daha yüksek olması, düşük sıcaklık ve yüksek nem isteyen ürünlerin depolama ömrünün daha az olması ve ürünlerin depolanma süresinin kısa olması gibi sakıncaları bulunmaktadır [5].

Yapay soğutmalı depolarda muhafaza: Soğuğun yapay olarak üretildiği ortamlarda gerçekleştirilen depolama sistemidir. Modern depolarda depolama süresi uzun ve ürün kaybı az, ancak depoların maliyeti yüksektir Çok pahalı ve işletilmesi güç kontrollü atmosferli depolar ancak yüksek kalite isteyen pazarlar için ve üretim garantisi olan durumlarda söz konu olabilir. Soğuk havanın elde edilmesinde kullanılan amonyak veya freon gazının farklı basınç ve ortamda genleşerek çevre 1sısını almalarını dolayısı ile ortamı soğutmasını sağlamak için soğutma sisteminin oluşturulması gerekir. Soğuk hava tesislerinde soğutmayı sağlayan sistem kompresör, kondenser, likit tankı, ekspansiyon valf, evaporatör ve soğutma kulesinden oluşur [14-15-3]. Soğuk depolamada en önemli girdilerden birini 
elektrik giderleri oluşturmaktadır. $\mathrm{Bu}$ nedenle yalıtımın kalitesi, soğuk hava deposunun karlılığı, sürekliliği ve ürün kalitesini korunması açısından da oldukça önemlidir [16].

Kontrollü atmosfer depolarda muhafaza: Ürünün etrafını saran atmosferi, normal atmosferdeki düzeyinden farklı olacak şekilde ortama gaz eklemek veya uzaklaştırmak yolu ile değiştirilerek, elde edilen ortamlarda ürünlerin muhafaza edilmesidir. Kontrollü atmosfer depoları; taşıma, geçici veya uzun süreli muhafaza sırasında kullanılabilir [17 ve 7]. Kontrollü atmosferli soğutma uygun 1sı, $\mathrm{CO}_{2}$ ve $\mathrm{O}_{2}$ karışımını sağlayacak şekilde hazırlanan havanın püskürtülmesi ile sağlanan yöntemdir. Kontrollü atmosfer, depolanan ürünün depoda kalma süresini artırmak, tazeliğini korumak amacı ile hava bileşimine müdahale edilerek hazırlanır [18].

\section{3. Çevresel Etmenler}

Tarımsal ürünler pazarlama aşamasına gelmeden önce mikrobiyolojik çürüme ve olgunlaşmadan dolayı bozulmaya maruz kalmaktadırlar. Depolanan ürünlerin, tüketilinceye kadar olgunlaşma ve geçkinleşmelerinin engellenmesi amacıyla olgunlaşma işleminin öngörülen zamanda en yüksek kaliteyi sağlayacak şekilde kontrol edilebilmesi istenir. Bu ürünlerin depolanma süreleri tür ve çeşidine, mikrobiyolojik gelişme, sıcaklık, nem, havalandırma ve atmosferin bileşimi gibi etmenlere bağlıdır [16].

Sicaklık: Depolama koşulları arasında en önemli etken olan sıcaklığın, ürünlerin bozulmadan kalitesinin korunması amacıyla belirli düzeyde tutulması gerekir. Soğuk depolarda 1Sı düzeyi depoya konulan ürüne göre değişir. En uygun 1s1, ürünü donma noktasına taşımayan, solunumu en az düzeye indirgeyen 1sıdır. Depo sıcaklığının düşük değerde olması yanında meyve sıcaklığının çok kısa sürede depolama sıcaklığına düşürülmesi de depo koşullarını etkileyen etmendir [19].

Hasat sonrasında ürün, bir dizi olgunlaşma ve yaşlanma olaylarının başlamış olduğu, aktif metabolizmaya sahiptir. Her bir olay ve bu olayların bütünü olan olgunlaşma için optimum dereceler varsayılmaktadır. $\mathrm{Bu}$ derecenin üzerindeki sıcaklıklarda olgunlaşmada anormallikler, altında ise yavaşlama görülür. Düşük sıcaklık solunumu yavaşlatır. Örneğin sıcaklığın $10{ }^{\circ} \mathrm{C}$ düşmesi ile solunum hızında 1/2-1/3 düşme gözlenir. Genel olarak olgunluğu hızlandıran, dayanma süresini kısaltan koşullar fizyolojik bozulmaları artırdığı için, düşük sıcaklık etkili korunma sağlar. Yüksek sıcaklık olgunlaşma metabolizmasını bozar ve yüksek sıcaklık zararlarını oluşturur. Ürünlerin solunumu, aromatik madde salgılanması, ürünün bileşimi, tat ve lezzeti bozulur, kalite düşer. $\mathrm{Bu}$ nedenle olgunlaşma ve olgunlaştırma en uygun sıcaklıklarda yapılmalıdır [20].

Bağıl Nem: Tarımsal ürünlerin depolanmasında en önemli etmenlerden birisi de su kaybının önlenmesi olup, bu ürünlere soğutma yanında yüksek bağıl nem de uygulanmalıdır. Nem oranı yeterli olmayan kuru depoda soğutma, su kaybına neden olarak ürün miktarında azalma, bozulma, buruşma ve iç kararmasına yol açar. Fazla nemli ortamlar ürün aromasında değişmelere, mantar hastalıklarına neden olur [21-15-19]. Bağıl nem, fiziksel bir faktör olup, hasat sonrasında üründen su kaybını etkileyen en önemli faktördür. Bağıl nemin olgunlaşma ve yaşlanma üzerinde doğrudan etkisi yoktur. Ancak aşırı su kaybına neden olarak kabuğun gaz geçirgenliğinin azalması durumunda, solunum ve metabolizmayı yavaşlatma etkisi söz konusudur [14].

Havalandırma: Depolamada sıcaklık ve nem kontrolü etkili havalandırma ve mekanik soğutucularla sağlanabilir. Havalandırmanın amacı, ürün yığını için düzgün hava akımı sağlamak ve 
sıcaklık ve bağıl nemi uygun sınırlarda tutmaktır. Havalandırma ayrıca depoda istenmeyen kokuların da dışarı atılmasını sağlar. Depoların etkili şekilde havalandırılmasıyla; ürünün soğutulması ve mevcut yara ve berelerin tedavisi için oksijen sağlanır, depo sabit ve homojen sıcaklıkta tutularak kayıplar en aza indirilir, olgunluğu hızlandıran aroma maddelerin belirli bölgelerde yoğunlaşması önlenir [19].

Ürün, içinde bulunduğu havanın bileşiminden etkilenmektedir. Havada metabolizmayı etkileyen gazlar oksijen ve karbondioksittir ve \% 79 oranında bulunan azot gazı ise etkisizdir. Depolamada düşük oksijen ve yüksek karbondioksitin etkilerinden yararlanılarak ürünün uzun süre tat ve lezzetini koruması sağlanır [14].

Diğer bir ortam faktörü olan ortam hava basıncının düşürülmesi, hava içindeki gazların miktarı ve dolayısıyla kısmi basınçların azalmasına yol açmaktadır. Örneğin hava basıncının \% 10’a indirilmesi oksijenin ortamdaki oranını da \% 2'ye indirir. Ürünün içindeki hava da bundan etkilendiğinden, içsel etilen miktarı da aynı oranda azalmaktadır [14].

\section{Yeraltı Depoları}

Kapadokya bölgesi başta olmak üzere tüf ağıllıklı alanlarda tarımsal ürünlerin depolamasında büyük üstünlük sağlayan yer altı doğal soğuk hava depoları, özellikle Kavak ve Ortahisar kasabalarında yoğunluk göstermektedir [22]. Günümüzde; bu katmanlar, patates ve narenciye ürünlerinin uzun süre saklanabileceği depolar haline getirilmiştir [23].

Tüfitler, volkan bacasından yüzeye çıkan $500-600{ }^{\circ} \mathrm{C}$ sıcaklıkta, asidik malzemenin (çoğunlukla küller) sedimanter ortamda çökelmeleri ile oluşan kayaçlardır. Tüfler, Volkan küllerinin tabakalar halinde birikmesi ile oluşan kayaçlardır. Volkanik küllerin konsolide hale gelmesiyle oluşmaktadır. Özellikle volkaniklere bağlı riyolit - dasit türü tüfit kayaçlar ilgi görmektedir. Bünyelerinde serbest olarak kuvars mineralleri bulunabilir. Tüfler sedimanter kayaçlar gibi tabakalanma gösterebilmektedir. Nevşehir-Ürgüp dolaylarında kısmen Hasandağ ve Acıgöl volkanlarından, çoğunlukla daha batıdaki Erciyes volkanlar topluluğundan Üst Miyosen-Pliyosende şiddetli patlamalarla havadan gelerek bölgedeki Neojen havzasında çökelen ve yığışan piroklastiklerin oluşturduğu tüfler ve ignimbritler geniş alanlarda yaygındırlar. Kalınlıkları yüzlerce metreye erişen bu birimler içinde eski insanlar tarafından kiliseler, mağaralar, evler ve yeraltı şehirleri yapılmıştır. Ihlara vadisi, Göreme, Üçhisar vb. mevkilerde bu yapılar çok ilginç görünümdedirler. Ayrıca yine yörede volkanitlerin daha sonra aşınmalarıyla oluşan peribacaları da doğada çok ender gözlenen oluşuklardandır [24].

Nevşehir yöresinin en önemli jeolojik unsuru, dünyaca tanınan turizm faaliyetleri bakımından önemli olan yüzey şekillerinin oluşma olanağı bulduğu Neojen-Kuvaterner yaşlı Ürgüp formasyonu içerisinde bulunan volkanik arazilerdir. Üst Miyosen-Kuvaterner sürecinde şiddetli volkanizma etkisinde kalan bölgede, kül akıntısı ignimbiritler olmak üzere volkanik malzemeler yayılış göstermektedir. Yumuşak karakterli tüflü yapı, 7. yy'dan itibaren yerleşmeye sahne olan yörede, insanlar tarafindan oyularak saklanma, korunma ve barınma amaçlı yerleşme şekline dönüştürülmüştür. Depolar, piroklastik akıntı çökelleri olarak geniş alanlar kaplayan sahalardadır [25 ve 22]. Tüf, tüfit, volkanik külden oluşan ve derinliği 50-300 m olan katmanlar, yüksek nem içeren higroskopik yumuşak yapısı nedeniyle kolay şekil alabilen ve hava ile temas ettiğinde sertleşen özelliği ile binlerce yıl önceki yeraltı şehirlerinin yıkılmadan günümüze kadar gelmesi mümkün olmuştur. Volkanik katmanlar 10 milyon yıl önce Miyosen 
devrinde aktif hale geçen Erciyes ve Hasan dağları arasındaki 180 km'lik alanı kaplamış ve volkanik hareketler milyon y1l öncesine, Pilosen devrine kadar devam etmiştir. Bu alanda en derin tüf katmanları Kayseri, Niğde ve Aksaray arasında Nevşehir bölgesine yayılmışıı [23].

Nevşehir yöresindeki volkanik tüf, silis $\left(\mathrm{S}_{\mathrm{i}} \mathrm{O}_{2}\right)$ başta olmak üzere (\% 68-69), alümin $\left(\mathrm{Al}_{2} \mathrm{O}_{3}\right)$ ve demir oksit $\left(\mathrm{Fe}_{2} \mathrm{O}_{3}\right)$ 'ten oluşmaktadır. Volkanik tüfün birim ağırlığı $1,26 \mathrm{gr} / \mathrm{cm}^{3}$ ve su emme oranı \% 30,4-44,75 arasında olup, Mohs ölçeğine göre sertliği 6,5-8,0 arasındadır. Volkanik aktivitelerle gazların birden bire ayrılarak soğumasıyla oluşan bu kayaların gözenekleri birbirine bağlantılı olmayıp, porozitesi \% 45-52 arasındadır. Bu nedenle bölgedeki volkanik tüfün termal iletkenliği çok düşüktür [6].

Yer altı depolarının yerüstü depolarından tek farkı yeraltında olmasıdır. Dizayn ve işletim sistemi aslında aynıdır. Hatta daha ekonomik işletim sistemine sahip olduğu söylenebilir. Üzerinde kışın oluşan donma sonucu kırıntılı yapı kazanan silikat minerallerinden oluşan örtü, yağmur ve kar sularını içine sızdırarak tüf materyalinin hava bulunan boşluklarını doldurur. Bu su, depodaki nemin sürekli yüksek olmasını sağlar. Mağarayı dışarıdan ayıran kalın tüf duvarlar, hava boşluklarının etkisiyle iyi bir 1S1 yalıtımı görevi de yaparlar. Yapısal olarak 2-3 m kalınlığındaki kolon ve duvar kalınlıklarının çok iyi yalıtımı ile yerüstü depolarından daha stabil depo içi sıcaklığına sahiptir. Günümüzde de başarıyla kullanılan ve gecenin düşük sıcaklığından yararlanılarak soğutulan bu depolarda sıcaklık, dış sıcaklık ortalamasının altındadır. Üstelik gece-gündüz sıcaklık farkı düşüktür. Sert kışlarda depo kapatılarak ürün dondan korunmaktadır. Depolardaki bağıl nem, toprağın neminden yararlanarak veya su serpilerek yüksek tutulmaktadır. Volkanik tüf, nemi dışarı atarken buharlaşma gerçekleşmekte, bu buharlaşmaya bağlı olarak depo içi sıcaklı̆̆ı düşmektedir. Kışın düşük, yazın yüksek sıcaklıktan korunan bu depolarda uzun depolama dönemi içinde sıcaklık 4-10 ${ }^{\circ} \mathrm{C}$, bağıl nem \% 85-90 arasında olmaktadır. Depo sıcaklığı dış sıcaklığa bağlı olduğundan, yüksek konumlu iç bölgelerde başarılıdır. Bu depolar düşük gece sıcaklıklarından daha iyi yararlanacak şekilde havalandırma ve nemlendirme ekipmanları ile donatıldığında, bazı dayanıklı tür ve çeşitlerin depolanmasında daha başarılı olmaktadır. Buna karşın depolama süresi, su kaybı, hastalık ve bozukluklar ve hızlı olgunlaşma nedeniyle oldukça kısalır. Ancak, bazı elma ve armut çeşitleri turunçgil meyveleri, kavun, patates, soğan vb. kök sebzeler saklanabilmektedir [14,20,6,23].

Genel olarak havalandırma doğal konveksiyonla, mekanik ekipmanlar kullanmadan yapı içi ve yapı dışı havasının farklı yoğunluklara sahip olması nedeniyle hava kütlesinin yer değiştirmesi ilkesi ile gerçekleşmekte ve sınırlı ölçüde kalmaktadır [14]. Yaz aylarında deponun kapıları ve havalandırmalar açılarak doğal yollardan soğutma yapılmaya çalışılmaktadır. Depolarda 5-6 m aralıklarla 25-30 cm çapında, 15-17 m yükseklikte havalandırma bacaları yapılmaktadır [22].

Yapay havalandırmalı yeraltı depolarında depo ile dış ortam arasında hava akımının olması için ortamlar arasındaki basınç farkı fanlarla sağlanmaktadır. Modernize edilmiş depolarda odalar grubu bir koridorla ayrılmış ve odaların arkasında odalara açılan havalandırma kanalı ve bir fan grubu bulunmaktadır. Fanlar dış havayı havalandırma tünelinden ürün yığını altına yerleştirilen borularla alttan üste doğru saatte 30000-40000 $\mathrm{m}^{3}$ olacak şekilde havalandırmaktadır. Bu depolarda odaların ısı ve bağıl nemi yı̆̆ı̆ndaki sensörler ile bir mikroişlemci tarafından kontrol edilmektedir. Koridor sonunda dışarıya açılan geniş bir baca ile ısınan hava ve karbondioksit dışarı atılmaktadır [23]. 
Doğal soğutmalı yer altı depoları, akarsu vadilerinin yamaçları boyunca volkanik kökenli tüflerin iş makineleri tarafindan oyularak galeriler açılması ile yapılmaktadır. Depolar, büyüklüklerine göre değişik sürelerde tamamlanabilmektedir. Orta ölçekli 1000-1500 $\mathrm{m}^{2}$ arasındaki deponun kazı işlemlerinin yaklaşık 45 gün sürdüğü belirtilmektedir. Alan arttıkça süre o oranda değişkenlik göstermektedir. Harfiyat ve kazı işlemlerinin önemli bir maliyeti de beraberinde getirdiği bilinmektedir [22]. Volkanik kayalar uzunlukları 10-200 m olacak şekilde koridor şeklinde delinmekte olup (Şekil 1) L veya U şeklinde de olabilmektedir [6 ve 23]. Günümüzde teknolojik gelişmeler sayesinde makinelerle içerisinde kamyon, tır ve araçların dolaşlabildiği büyük ürün depolama alanları haline gelmiştir. Bu nedenle depoların yerden yükseklikleri 4,8-5,5 m, genişlikleri 4-6 m arasında değişmektedir [22].

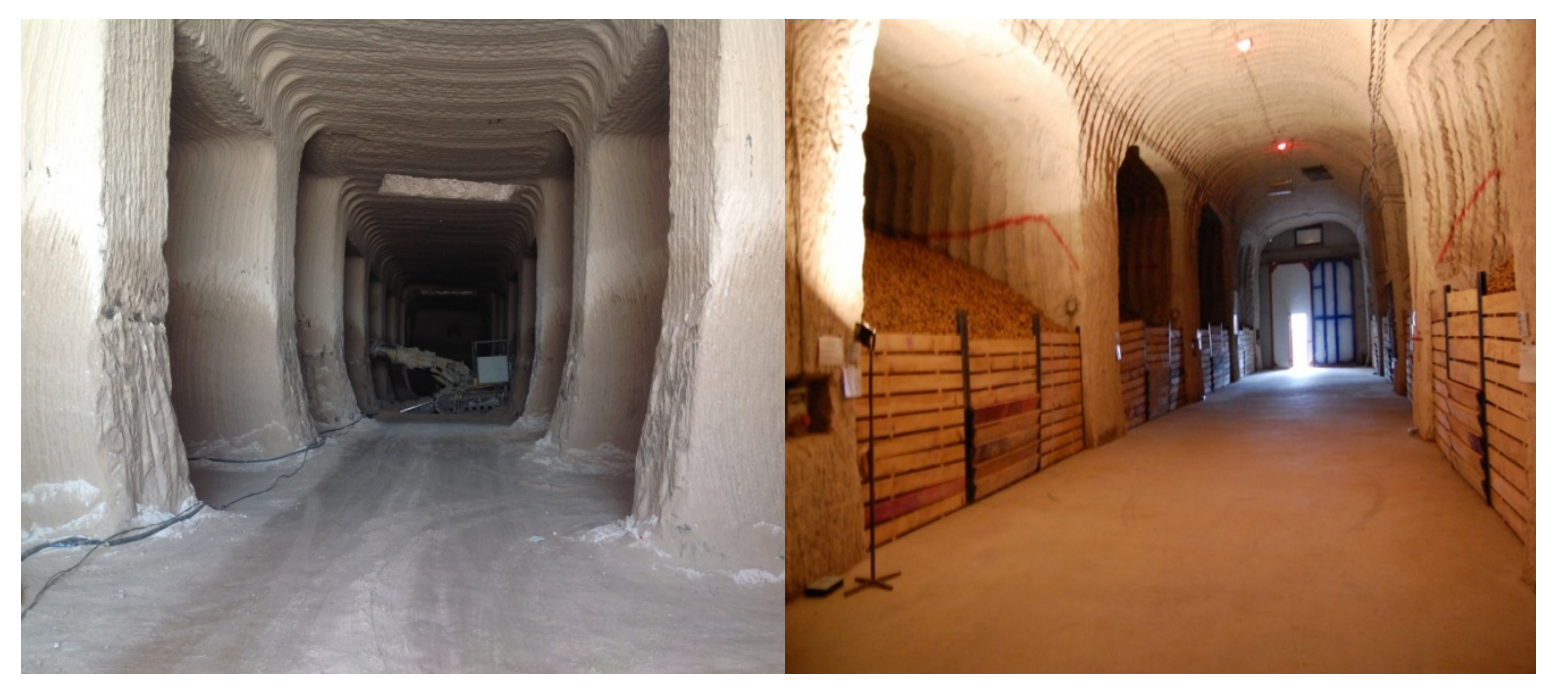

Şekil 1. Doğal soğutmalı yeraltı deposu (Anonim 2015)

Depo alanlarının üzerinde havalandırma bacalarının bulunması, tarımsal faaliyetleri sınırlandırmaktadır. Bazı depoların üzerinde bağcılık faaliyetleri yapılmaktadır. Ayrıca depolar yerleşimlerin gelişim yönünü de belirlemekte olup, açılan galerilerin üzerine konut yapımı risk oluşturduğundan, depolar yerleşim alanlarının çevresinde yer almaktadır [22].

İklimlendirme sistemi (soğutma veya 1sıtma) olarak herhangi bir ekipmanın kullanılmadığı bu depolarda ürünlerin depolanması büyük maliyet üstünlüğü sağlamaktadır. Bu maliyet üstünlüğünden yararlanmak isteyen birçok ticari firma, depolama için volkanik tüf depolarını tercih etmektedir. Nevşehir yöresinde ekonomik yönden yöre insanına önemli yararlar sağlayan ve farklı sertlikteki tüflerin oyulmasıyla oluşan $500000 \mathrm{~m}^{3}$ depo hacminin bulunduğu bildirilmektedir [20]. Yalnızca Kavak ve Ortahisar'da 500'ün üzerinde doğal soğutmalı yer altı deposu hizmet vermektedir. Bölgedeki yeraltı depolarının çoğu 100-1000 tonluk bir ya da birkaç galerilik küçük ve orta ölçekli depolar halinde olup Kavak, Ortahisar, Şahinefendi, Kelah, Kaymaklı, Mazı, Nar ve Çat köyleri mevkilerinde bulunmaktadır. Son yıllarda ise planlı-projeli tesis edilen 5000-20000 ton kapasiteli depolar, patates endüstrinin gelişimi ile birlikte artmıştır [23]. 
Yöredeki yoğun depolama yapılarından kaynaklanan farklı bir ekonomik faaliyetin ortaya çıktığı görülmektedir. Örneğine pek sık rastlanmayan yöre, doğal depoculuk faaliyetlerinde Türkiye'de söz sahibi bir konumda bulunmaktadır. Doğal soğutmalı yer altı depolarına ürünler farklı yörelerden gelmektedir [22]. Yörede tohumluk patates üretiminin artması, turunçgilin pazarlanmadan önce depolanması gerekliliği ve depolanan ürünlerin bozulmadan uzun süre saklanılması, bu depolara olan talebi artırmaktadır. Depolarda başlıca limon ve patates saklanmaktadır. Türkiye'de üretilen patatesin yaklaşık yarısı Niğde-Nevşehir yöresindeki volkanik tüf depolarda muhafaza edilmektedir. Bölge potansiyeli için ülke ekonomisine büyük katkı sağlayan ve ülkenin kışlık patates gereksinimini karşılayan yer altı depolarında yaklaşık 10 milyon sandık limon ve narenciye depolama kapasitesi bulunmakta olup, 1,5 milyon tonun üzerinde patates dönüşümlü olarak depolanabilmektedir. Ürünlerin yetişme dönemlerine göre depoların kullanım evreleri değişmektedir. Daha çok Niğde, Nevşehir, Sivas, Konya, Afyon, İzmir, Adana'dan gelen patatesler Eylül, Ekim aylarında volkanik tüf depolarına konulmakta ve 6-8 ay Mayıs ayı sonuna kadar özelliklerini kaybetmeden depolanabilmektedir. Mersin ve ilçelerinden gelen limon, Ocak sonu, Şubat başında depolanmakta olup Eylül, Ekim aylarına kadar depolanabilmektedir. Ortalama depolama periyodu patates depolarında sekiz aydır. Depolama döneminin sonunda depo duvarları basınçlı su ile yıkanmakta, hastalık ve zararlılara karşı da önlem alınmaktadır.

\section{Sonuç}

Ürünlerin deriminden sonra ürün kalitesinin korunması, zararların önlenmesi, tazeliğini korumaları, ağırlık kaybının azaltılması, solunum hızının yavaşlatılması, su kaybının en aza indirilmesi, bünyesindeki mikroorganizma faaliyetlerinin azaltılması ve yaralanma etkisinin en az düzeye indirilmesi ancak uygun koşullara sahip depolarda depolanmasıyla olasıdır.

Çeşitli iklim özelliklerine sahip olan ülkemizde, Nevşehir yöresindeki tüf kayalarına (yapay mağara) oyulan depolarda kış aylarında sıcak, yaz aylarında ise serin olan doğal soğutmalı depolarda iklimlendirme sistemi olarak herhangi bir ekipman kullanılmadan yalnızca deponun soğuk havasından yararlanılarak binlerce ton yaş sebze ve meyve hiçbir enerji harcanmadan depolanabilmekte, bu da büyük maliyet üstünlüğü sağlamaktadır. Kayadan oyma depolarda depolanan ürünlerde klasik depoların aksine kayıp oluşmamakta, sabit ısı ve nem dengesi gibi özelliklerinden dolayı, depolanan ürünlerin doğal yapısı bozulmadan muhafaza edilmesi sağlanmaktadır. Bu tip depoların basit yardımcı düzenlerle daha etkili ve başarılı bir şekilde çalıştırılması her zaman mümkündür. Bacasız fabrikalar özelliğindeki depolar, ülke ve bölge ekonomisine büyük katkılar ve önemli istihdam olanağı sağlamaktadır. Bölgede kullanılan doğal soğuk hava depoları, son yıllarda büyük sanayi kuruluşlarının da dikkatini çekmekte ürünlerinin uygun koşullarda muhafazası için doğal soğuk hava depolarını tercih etmektedirler.

\section{Kaynaklar}

[1] Karaman, S., Okuroğlu, M., Kızıloğlu, F. M., Memiş, S., Cemek, B., "Karaman ili iklim koşullarına uygun elma depolama yapılarının planlanması" 1. Elma Sempozyumu, 135-144, Karaman, 2009.

[2] Memiş, S., M. Okuroğlu, S.,. Karaman, ve Şirin, Ü., "Tokat ili iklim koşullarına uygun örnek domates depolama yapısı" Tokat Sempozyumu, Cilt II., 01-03 Kasım, 473-483, Tokat, 2012 
[3] Ekmekyapar, T., “Tarımsal Yapılar” Atatürk Üniv., Zirat Fak. Yay., No:204, Erzurum, 2001.

[4] Polat, R., "Bazı Elma Çeşitlerinde Soğuk Depoda Muhafaza Şartlarının Belirlenmesi Üzerine Araştırma" Gaziosmanpaşa Üniversitesi, Fen Bilimleri Enstitüsü, Y. Lisans Tezi, Tarım Makineleri ABD, Tokat, 73 s. Tokat, 1994.

[5] Okudum, R., "Soğuk hava depolarının dağılışı ve coğrafi analizi” Süleyman Demirel Üniversitesi, Sosyal Bilimler Enstitüsü, Coğrafya ABD, 206s. Isparta, 2012.

[6] Öztürk, T., "The potato storage in the volcanic tuff storages in Turkey" Gaziosmanpaşa Üniversitesi, Ziraat Fakültesi Dergisi, 27 (2), 113-120, Tokat, 2010.

[7] Altuntas, E., Karaman, S., “Tarımsal ürünlerin depolanması ve kalite özelliklerine etkileri” 12. Ulusal Kültürteknik Sempozyumu, 21-23 Mayıs, Tekirdağ, 2014.

[8] Karaçalı, İ., “Bahçe Ürünleri Muhafazası Ders Kitabı” No: 494, Ege Üniversitesi, İzmir, 1990.

[9] Öztürk,T., “Tarımsal Yapılar” OMU, Ziraat Fakültesi Yayınlarl, No: 49, Samsun, 2003.

[10] Alkan, Z., “Zirai İnşaat” Atatürk Üniversitesi Basımevi, 252/A, Erzurum, 1972.

[11] Anonim., “http://www.patates.gov.tr/” Niğde Patates Araştırma Enstitüsü Müdürlü̆̈̈ü, Niğde, 2006.

[12] Anonim., "Pazarlama ve Parakende” Milli Ĕgitim Bakanlı̆̆̆, Sebze ve Meyve Satışı, 342PR0080, 55s, Ankara, 2011.

[13] Sayıll, M., Batu, A., Tokatlı, M., Yıldızlı, M., "Tokat İlinde Meyve ve Sebze Depoculuğunun Mevcut Durumu, Sorunları ve Çözüm Önerileri” Guda Teknolojileri Elektronik Dergisi, (3) 2736, 2006.

[14] Karaçalı, İ., 1993. "Bahçe Ürünleri Muhafazası ve Pazarlaması" Ege Üniversitesi, Ziraat Fakültesi Yayınları, No: 494, İzmir, 1993.

[15] Coşar, F., "Isparta Yöresinde Elmacılık ve Depolanması ile Depolama Maliyetlerinin Tek Düzen Hesap Planına Göre Hesaplanması” Süleyman Demirel Üniversitesi, Sosyal Bilimler Enstitüsü, İşletme ABD, Isparta, 128s, 1997.

[16] Alkan, Ü, 2013. "Aydın İlindeki Soğuk Depolama Yapılarının Mevcut Durumunun Belirlenmesi ve Geliştirilmesi” Adnan Menderes Üniversitesi Fen Bilimleri Enstitüsü Y. Lisans Tezi, Tarımsal Yapılar ve Sulama ABD, Aydın, 78 s, 2013.

[17] Anonim, "http://www.bahcesel.com/forumsel/genel-bahce-bitkileri-kitabi” 2010.

[18] Özkol, N., "Uygulamalı Soğutma Tekniği” TMMOB Makine Mühendisleri Odası Yayını 115. 1985.

[19] Karaman, S ve Cemek, B., "Tokat yöresi iklim koşullarına uygun elma depolama yapılarının planlanması" V. Ulusal Bahçe Bitkileri Kongresi, 4-7 Eylül, Erzurum, 2007.

[20] Karaçalı, İ. "Bahçe Ürünlerinin Muhafazası ve Pazarlanması" Ege Üniversitesi Ziraat Fakültesi Yayınları, No: 494, Bornova, s.486, İzmir, 2009.

[21] Özdemir, A.E., "Pozantı Kamışılı vadisinde yetiştirilen Amasya Starking ve Golden Delicious elmalarının muhafazası üzerinde araştırmalar I. Derim Zamanının saptanması” Doğa, 16, 519527, 1993. 
[22] Boyraz, Z., Zeren, C., "Kavak ve Ortahisar (Nevşehir) kasabalarındaki doğal soğutmalı yer altı depoları" ZfWT Zeitschrift für die Welt der Türken Journal of World of Turks ZfWT. s:23-40. Vol.4, No: 1, 2012.

[23] Anonim, "Doğal yeraltı depoları"

http://www.dogaseed.com/tr/faaliyetlerimiz/depolama/dogalyeraltidepolari,2015.

[24] Kaygısız, H., "Kayseri Yöresindeki Yapıtaşlarının Fiziko-Mekanik Özelliklerinin Belirlenmesi”. Çukurova Üniversitesi, Fen Bilimleri Enstitüsü Y. Lisans Tezi, Maden Mühendisliği ABD, 75s, Adana, 2010.

[25] Dirik, K., 'Kapadokya Bölgesi’nin jeolojisi, jeomorfolojisi ve bunların bölgedeki medeniyetler üzerindeki etkisi” 1. Tıbbi Jeoloji Çalıştayı, 30 Ekim-1 Kasım, Ürgüp/ Nevşehir, 2009. 